\title{
STUDIES ON THE CHEMOTHERAPEUTIC EFFECT ON THE RAT-LEPROSY
}

Part 1. On the Preventive and Therapeutic Effects of Promacetin, Proethyl and Cepharanthin, especially of their Combinations on the Rat-Leprosy.

- STUDIES ON THE RAT-LEPROSY (23) -

YASUSHI NOBIRA

Department of Bacteriology (Director: Prof. K. Urabe), Hiroshima Medical School.

The present paper is a report on the preventive and therapeutic actions of the newer chemotherapeutics, Promacetin and Proethyl, and, especially, on their combined effects with Cepharanthin on the development of the experimental rat-leprosy.

The results were as follows:

(1) Promacetin and Proethyl apparently possessed the preventive and therapeutic properties against the rat-leprosy, and the improvement noted in the animals treated with Promacetin was certainly more striking and rapid than that observed in those treated with Proethyl.

(2) So far as the present combined dosage of Cepharanthin, it did not potentiate the action of Promacetin or Proethyl, and appeared rather to be antagonistic against that.

(3) Although the therapeutic effect of Cepharanthin on the rat-leprosy is much or less able to be expected, the further trials are required as to its dosage.

(Author's abstract)

\section{鼠瀨の化学療法に関寸る研究(第 1 報) \\ Promacetin, Proethyl 及び Cepharanthin の 単独並にそれ等の併用投与の鼠癩に対省万発症 阻止亚に治療効果について \\ 一鼠攋 の研究 (23) - \\ 应鼠医科大学桄囷学教空 (主任 占部教授) \\ 野 \\ 本 \\ 靖}

(昭和 28 年6月 29 日受稿)

(この研究の1 部は文部省科学研究費によつた。占部)

\section{緹 言}

近時，わ加国心於て 4,4-Diuminodiphenylsulfone 誘導体で心る Fromin, Diasone, Promizole の人蜊に対

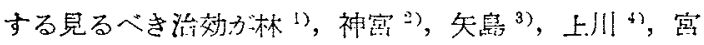

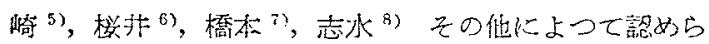

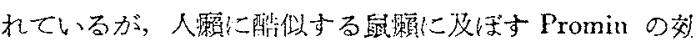

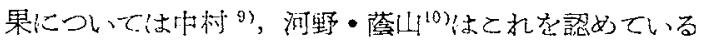

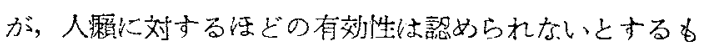

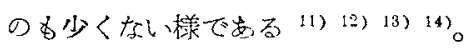

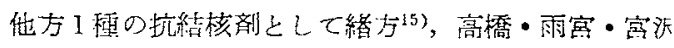

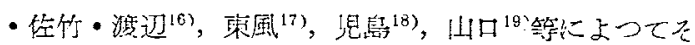


の有效性ガ認女られたととの点る Cepharanthin る活制 剂として, その有效性が吉田 ${ }^{20)}$, 光田 ${ }^{21)}$, 山队” ${ }^{22)}$, 橋本 -古見・赤崎・小山・田中・木根・明石・是立・飯野・ 佐藤・矢帛・脣行川・武田23等によつて報告されたが， 反面このものの人顀に対する整効老報告した業績も少く

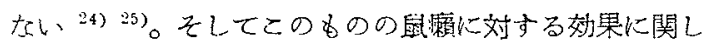

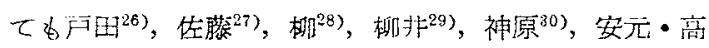

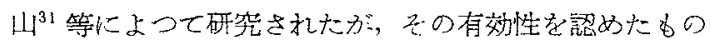

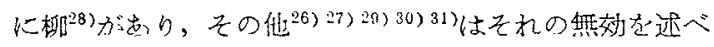
ている。

さて，私は近時米国に於て洁瀨効果があるとして注目

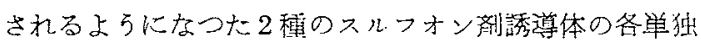
投与,峏者の解朋投与,並化それ的と Cepharanthin との

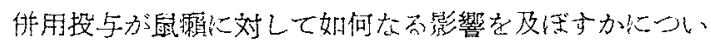
て実験したので以下報皆する。

\section{芽 1 章 実 験 法}

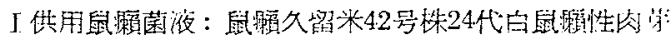

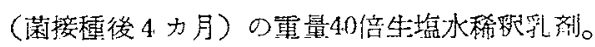

II 供試薬品: 吉富製薬の奸琴による Promacetin（4,4'-DiaminodiphenyIsulfone-2-acetylsulfonamide $大$ 瓜 維成を有する白色結疁性粉末で水に是滨，以下PM 之略 す) 历ぷ Proethyl (4-A mino-4i'-R-hydroxyethylaminodiphenylsulfone なる組成を有する白色結品性特末

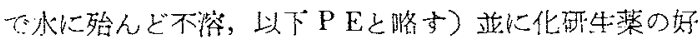
意によるCepharanthin（以下CPと略す）を使用した。

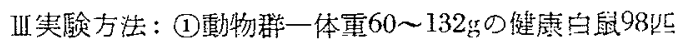

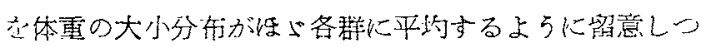

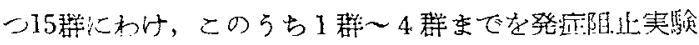

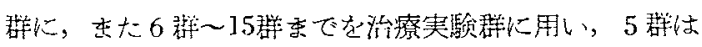
焎姑置対照群とし，それらの編成は，1群 (PM投与)

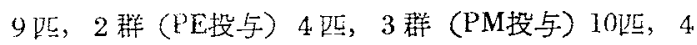
群 (PE投与) 5 味，5裙 (刘招) 6 匹，6群(PM投与) In匹， 7 群 (PE投与) 5 味，8 群 (CP投与) 10匹品，9

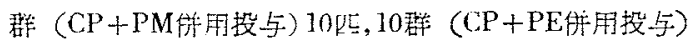

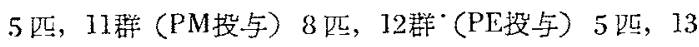

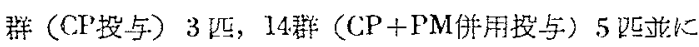
15群（CP+PE搠用投与）3匹ととた。

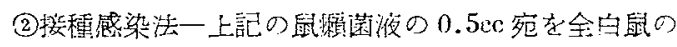
右側滕べき部芝下に揆種した。

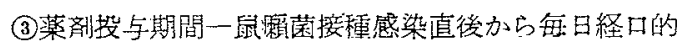
にPM又はPE走 1，2 群以は 8 週間，3，4群には11週

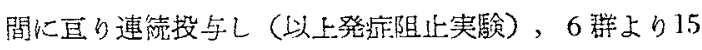

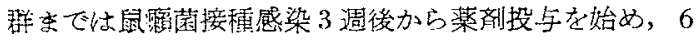

$7,8,9,10$ 群にはPM, PE, CPの备単独, $\mathrm{PM}$ と $\mathrm{CP}$ の併用亚にPEとCPの航用の各投与を 8 䓢間に亘り続

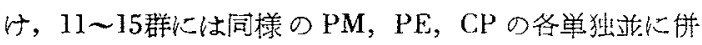

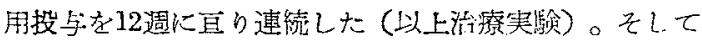
署殺剖検は全群いずれす投与中止後直らに実施した。

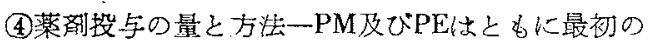
2 涸間は每日2.5mgずつを経口投与し，次の 2 週間は整

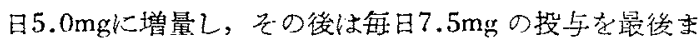
で級けた。CPは每邀 2 回 $1.0 \mathrm{mg}$ ずつを左側膝べき波下 に注射した。倘，薬郕併用の場会は上記のPM开はPEの 1 日量に每通 2 回 $1.0 \mathrm{mg}$ ずつのCP皮下注射を併用し た。

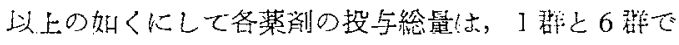

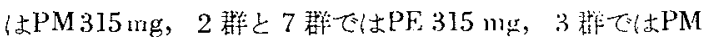
$472.5 \mathrm{mg}, 4$ 群ではPE $472.5 \mathrm{mg}, 8$ 䛎ではCせ $16 \mathrm{mg}$,

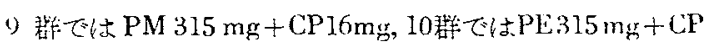

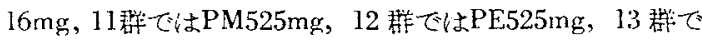
: $525 \mathrm{mg}+\mathrm{CF} 24 \mathrm{mg}$ となつた。

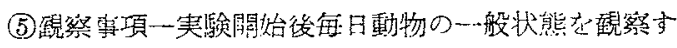

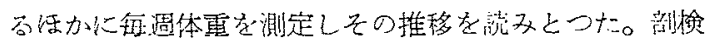

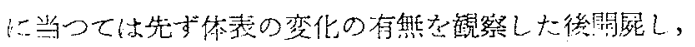

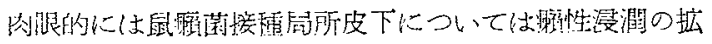

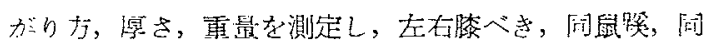

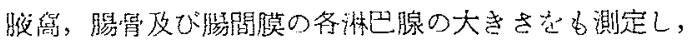

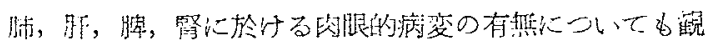

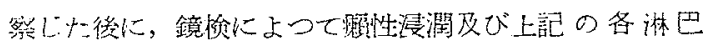

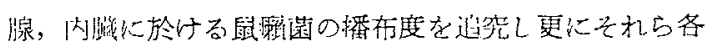

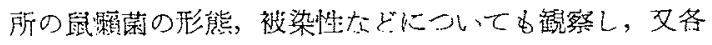
部位の病理組織学的所見についてもへマトキシリン・エ オヂン染色によつて㭘訫した。

\section{第 2 草 実 驗 成 績}

実駼战綪の詳細についての表は余りにも龙大になるの

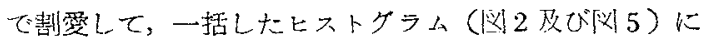
よつて示すこととした。

A. 発症阻止実験成辚＝感染直後よりPM 以びPEの投 楽開炲群 $(1 \sim 4$ 群) Kつい,

1. 生存期間 (=投薬期間)：1 群 (PM単独，9员）

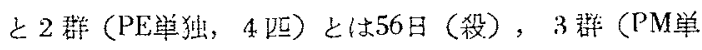

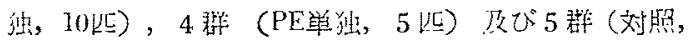
6 15) はいずれも77日(殺)でせつだ。

II一般状熊：1５群凡て体表变化㓌性。食愍は1 小群に於て投薬關始当初並儿投莧量を增量した数日間は 減退したが間るなく頜愍となり元気を问復した。賴便並 


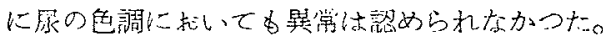

III 伶雷の推移：奻花鼠の多い群では体重の增北率は大

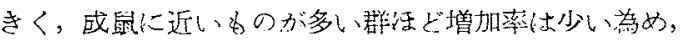

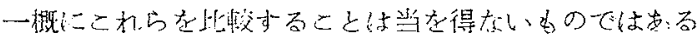

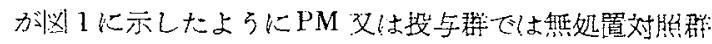
に比して少くとも体重の成少する上らなととはなく，む しろその堌加率はより大きい倾间さ之見られた。

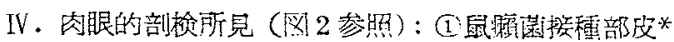

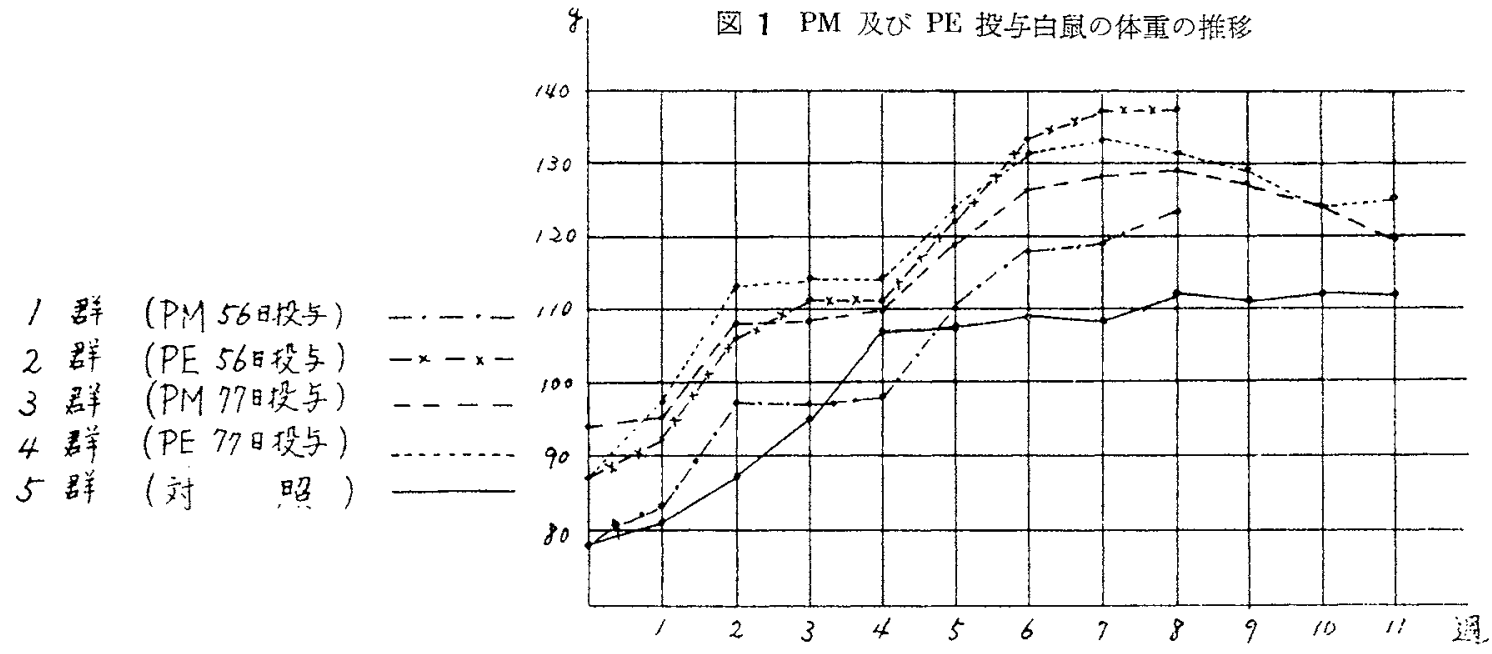

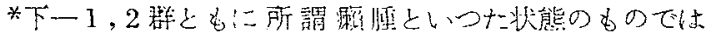

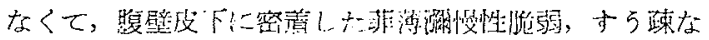

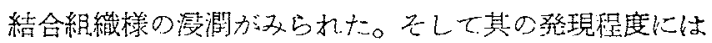

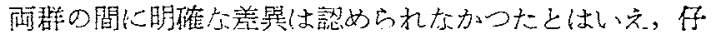

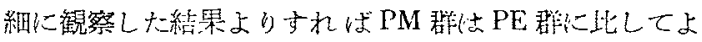

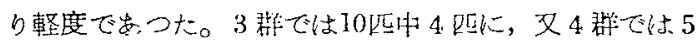

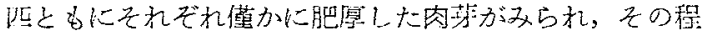

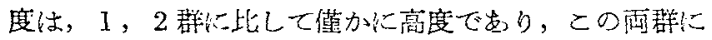

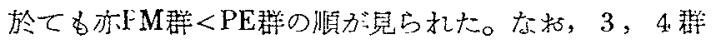

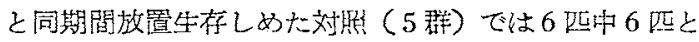
もに肥厘し大肉萝結節の形成が㫕られその程度は3，4 両群のそれらに比してかたり高度で出つた。

(2) 淋巴腺脚（てれは鼠獭以外の原因によつてb引き

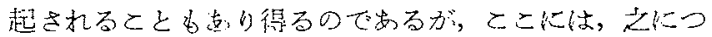
いてはしばらく諭外として迟べるとと之する。）一左在

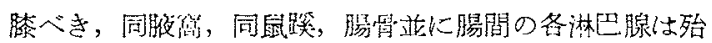

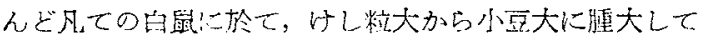

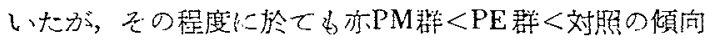

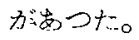

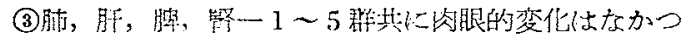
た。

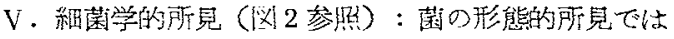

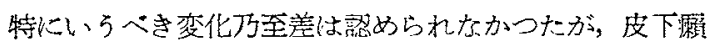

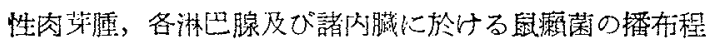
度は图 2 の上らに，1 群と 2 群とでは 2 群の方が，文 3

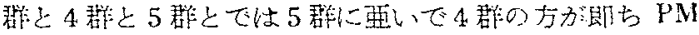

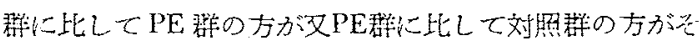
れでれより大で㝒つた。

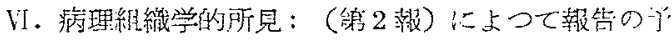
定。

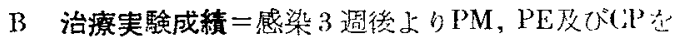

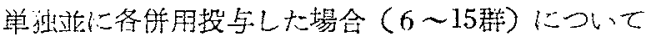

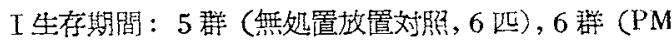

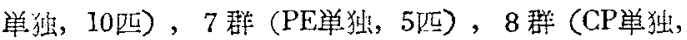

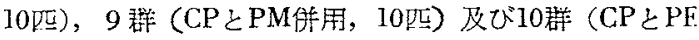

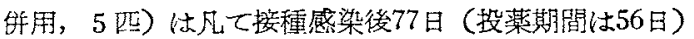

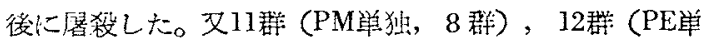

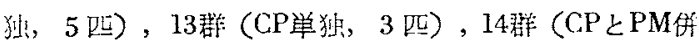

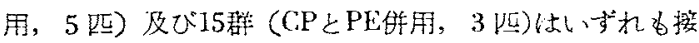

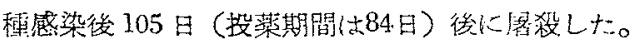

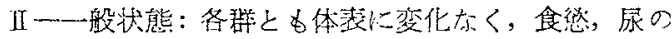

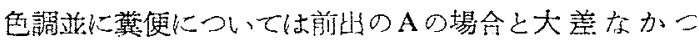
to

正体重の推䔟：汹 3 及文び図4に示したよ5に

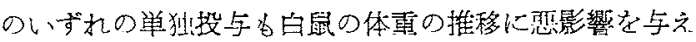
ることはなかつたようで步つたが，ただCPのみは今何 の投与量では线分週量でめつたためか，てれ単独投与の 祭には稳々著明に，又 PM或はPEと併用し大之きには

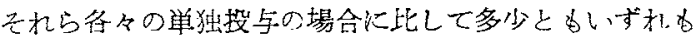
体央の增圾率が低下したよらで台つた。 


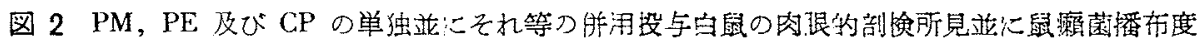

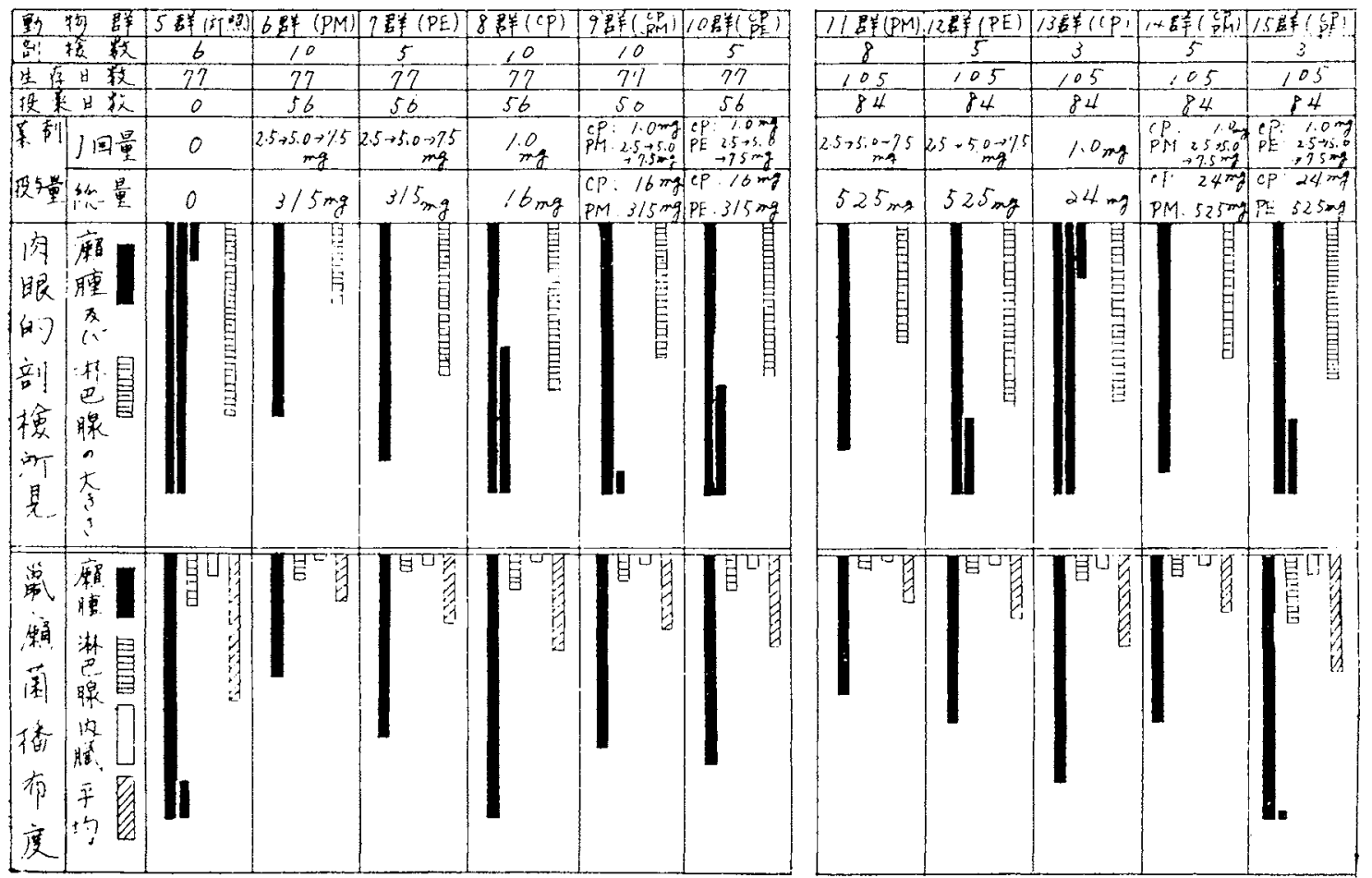

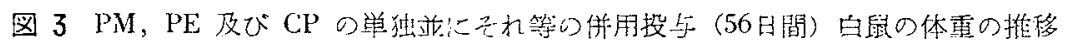

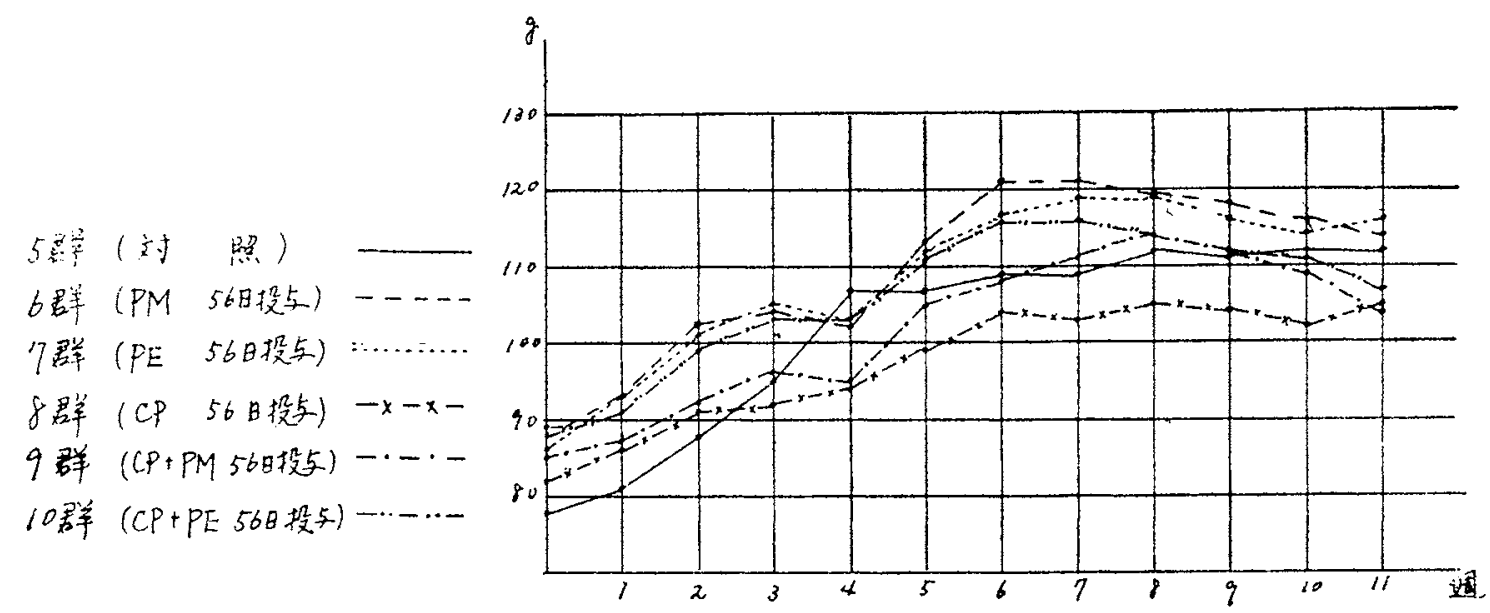

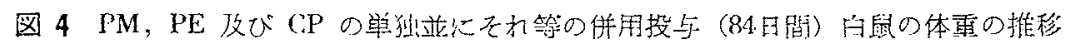

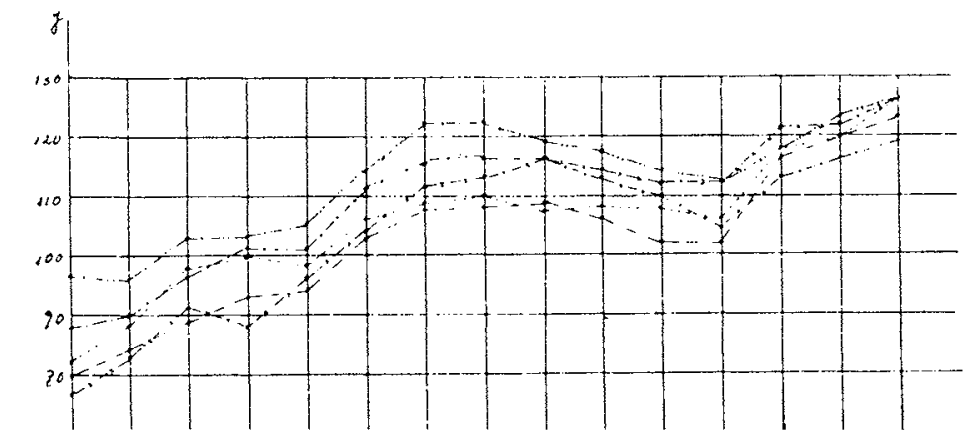




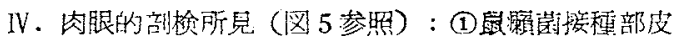

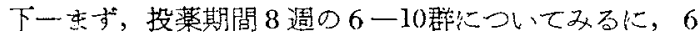

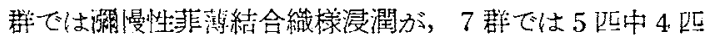

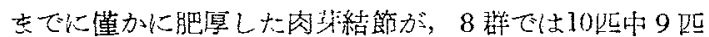

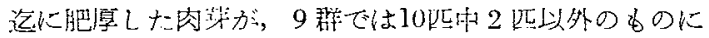

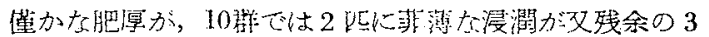

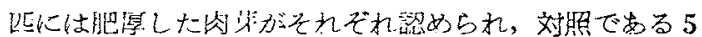

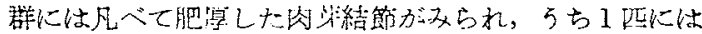

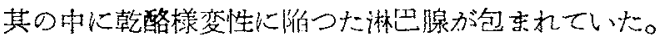

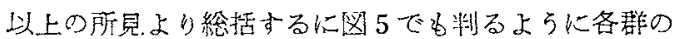

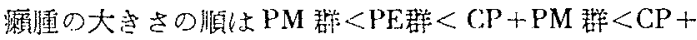

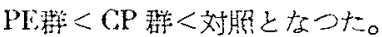

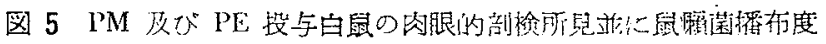

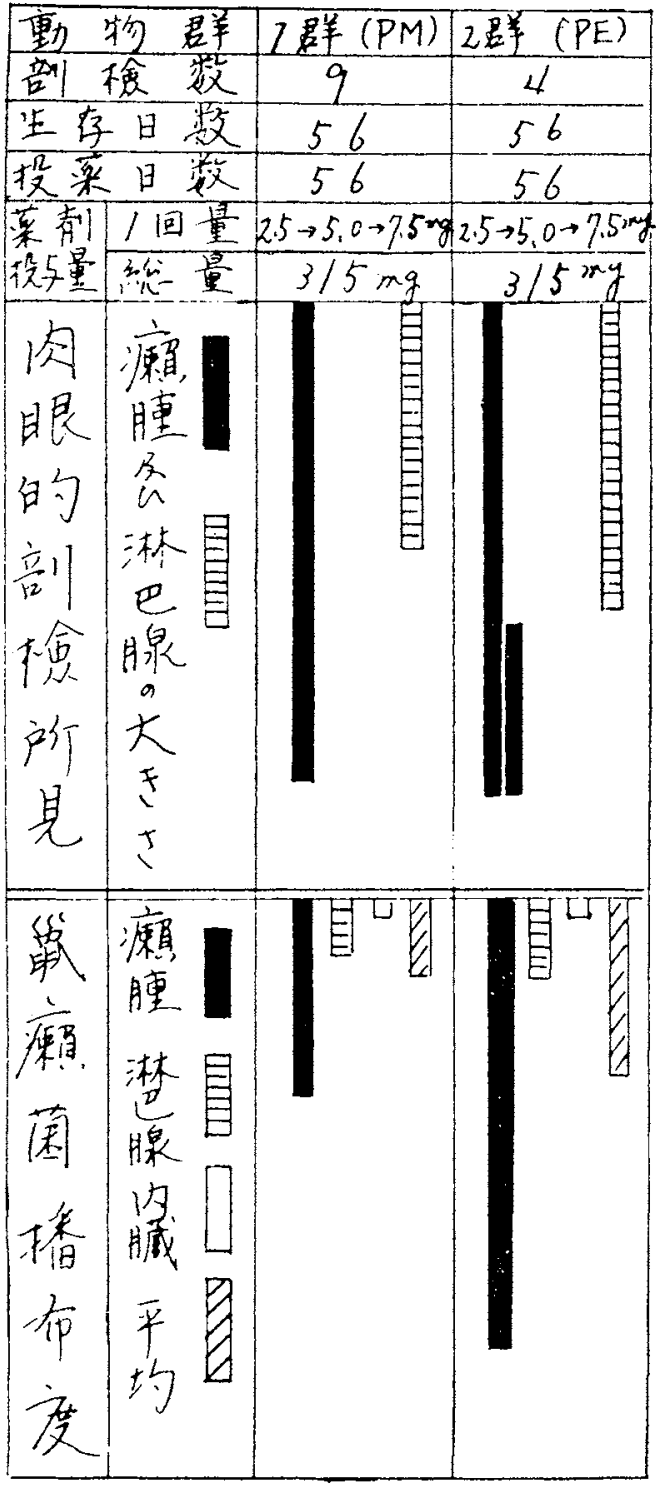

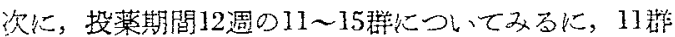

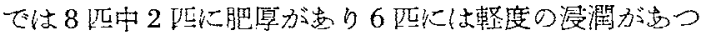

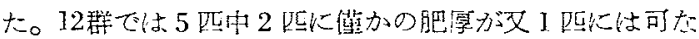

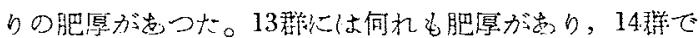

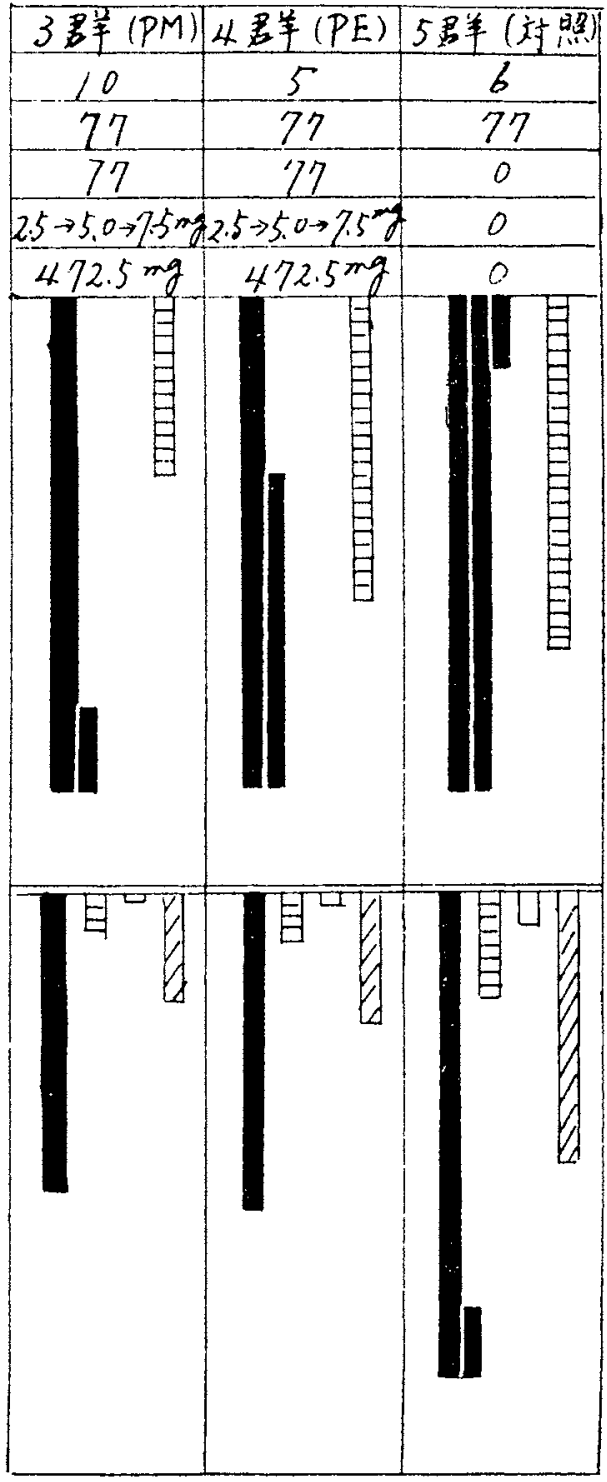

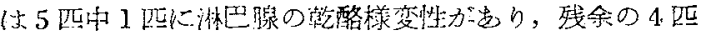

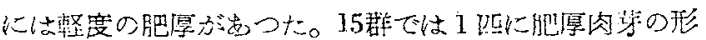

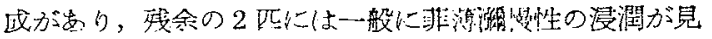
られた。 


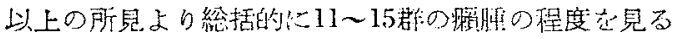

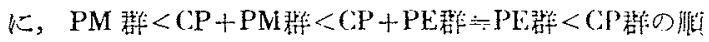
になることが分つた。

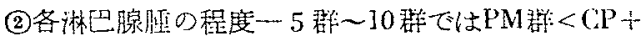
$\mathrm{PM}$ 群 $<\mathrm{PE}$ 群二CP+PE群 $<\mathrm{CP}$ 群<対照群の順になり： 11 群〜15群でく $<$ CP群の順となつた。

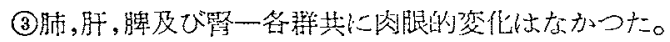

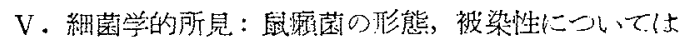

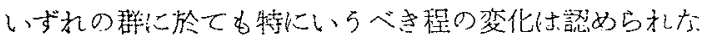

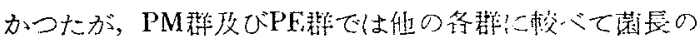
知いるのが多い㦈でつた。

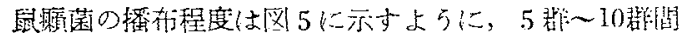
ではPM群 $<\mathrm{PE}$ 群 $<\mathrm{CP}$ 群+ $\mathrm{PM}$ 郡 $<\mathrm{CP}+\mathrm{PH}$ 格 $<\mathrm{CP}$ 群<

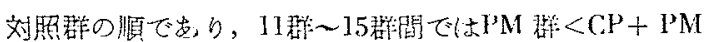

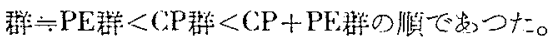

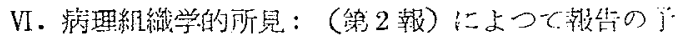
定。

\section{総括並に挎按}

以上の成綪を総括するに, PM胢いて Johansen 等:

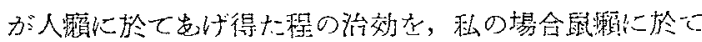

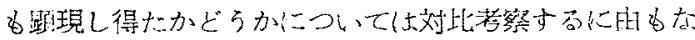

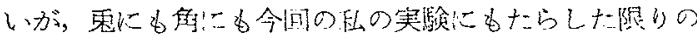

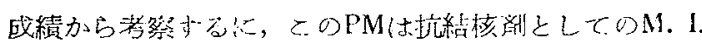

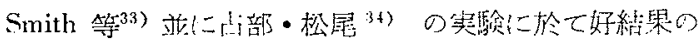

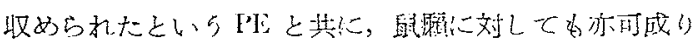

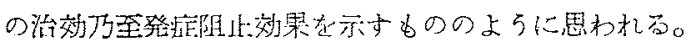

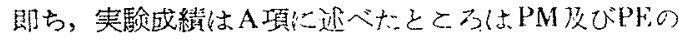

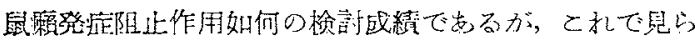

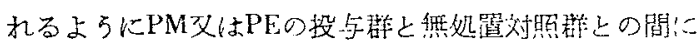

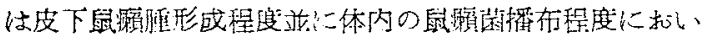
て相当の關があり，更にそれらの所見を綜合すれてば鼠鼠

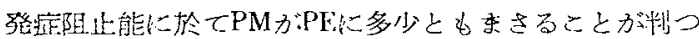
to

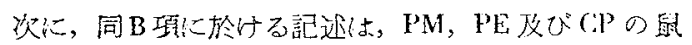

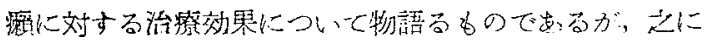

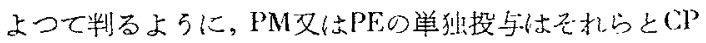

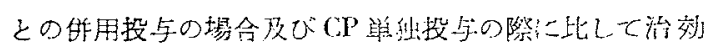

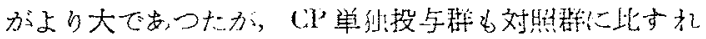

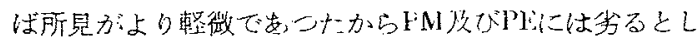

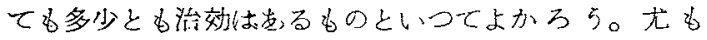

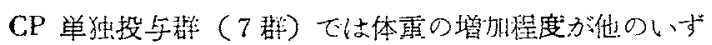

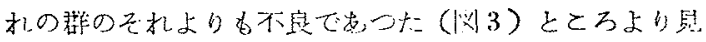

ると命同のCPの投与量が多きに先したのではないかと

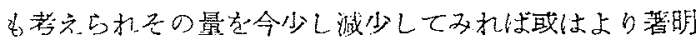
た治效も期待できるのではないかと思い，CPの上り微

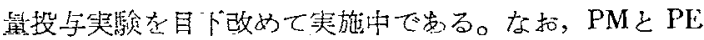

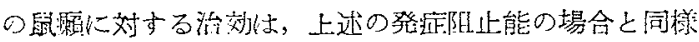
PEに比してPM の方がロ卡であつた。てしてCPは今

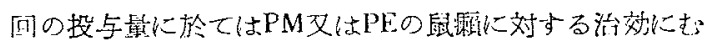
しろ拮抏するのではないかと舁われたがこの点に䦎して

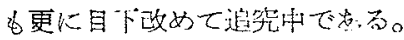

教室の占部・松尾 ${ }^{34)}$ (結核园に対してのPM造にPEの

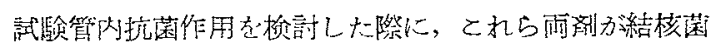

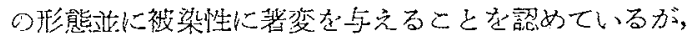

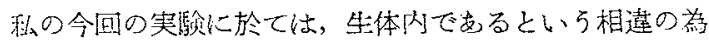
か鼠膨菌にはをのよらなととは砝ど見られなかつた。并

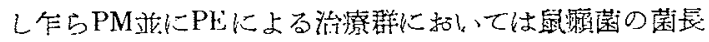

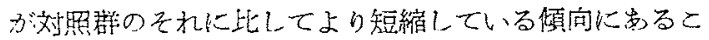
とが確認されたととは與味がある。

最後に供試PM，PE及びCPの毣性についてでるが， 今回の使用量の限りではPM及びPEには白瓦に対して何

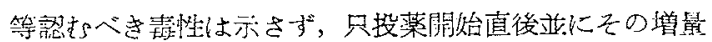
真後に際し一過性の食笖減退に伴ら体重の減少を芫た

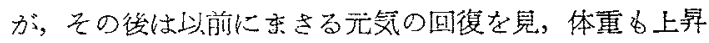

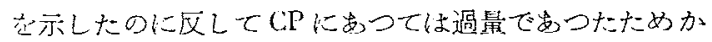
由鼠の食愍減退し従つて体重の增加率女最子不良で员つ

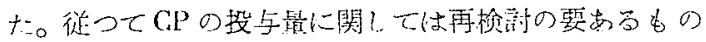
と侾えら机る。

\section{結 論}

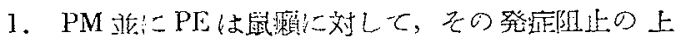

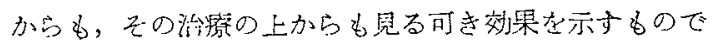

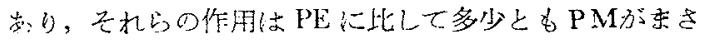
つている。

2. PM㫫にPEにCPを䑙用すること伿今间のCP使用

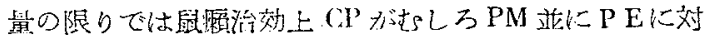
して多少とも持抗的に作用するよらになるるののよ5で 灾。

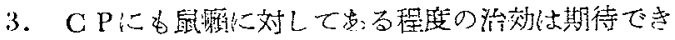

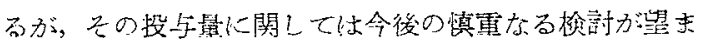
方る

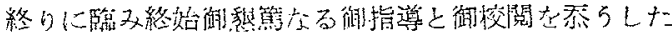

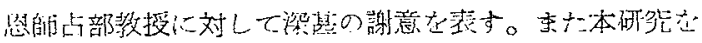

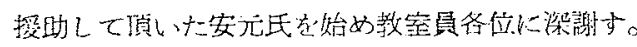

\section{主要文献}

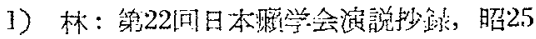


2) 神客:

问 $t$

3) 失息:

同 $上$

4) 上II:

同 上

5) 富猗:

同上

6) 核护:

周比

7) 鹤本:

[i.] $t$

8) 志水:

闹上

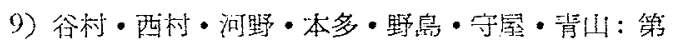
21回日本筑学会報告, 昭24

10）作藤・真山・荒喜：同占

11) 北村・欲奥：瀜上

12）神原：レブラ，17，(4)，65, 昭23

13) 中村：レブラ, 19, (5)，21, 昭25

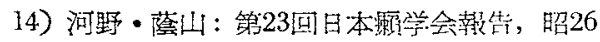

15）緒与：化学爎法研究所笨報， 1, (1)，4, 昭21

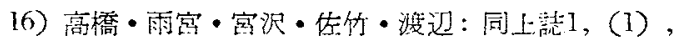
36 , 昭 21

17) 東咱：同上訫， $1 ，(2) ， 85$, 昭 22

18）缇島：同上誌，1，(2)，90，昭22

19) 出口: 同上誌，3，(1４)，41, 昭21

20) 喈田: レブラ，16，（3），34，昭22

21) 光田: 日本医学, (3389)，10, 招19

22）山附：皮周科性病科雑誌，56，（2），I5，昭21

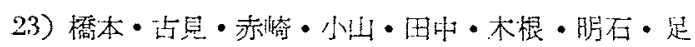

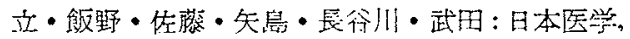
(3383)，11, 昭19，

24) 佐谷・㣟村：レプラ，15，(4)，289，昭19

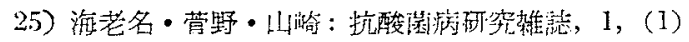
1 , 昭2]

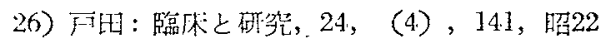

27) 佳藤：レブラ，18，(特别号），29，昭24

28) 柳：医学研究，21，(8)，104, 昭26

29) 柳非：レブラ，20，(1)，22，昭26

30) 神原：レブラ，17，(4.)，65, 昭23

31) 安元・蝗山：レブラ, 投槁中

32) F. A. Johansen, P. T. Erickson, R. R. Wolcott, W, H, Meyer, H. II. Gray, B. M. Prejean, and S. H. Ross : Promacetin in Treatment of Ieprosy. Pub. Hcalth Rep., $65,(7), 195 \sim 207$, 1950)

3.3) M. I. Smith, F. L. Jackson, J. M, Junge, and B. K. Bhattachar : The Pharmacologic and Chemotherapeuti: Action of Some New Sulfone \& Streptomycin in Experimental Tuberculosis, Am, Rev, Tho; , 60, (1) , 62 77, 1949

3.1）应部・松寻：Hiroshima J, Med, Sci, , 1, (4), 1953 揭载分笔 